\title{
A New Species of Deep-sea Nematode, Micoletzkyia mawatarii sp. nov. (Nematoda: Enoplida: Phanodermatidae) from Northern Japan
}

\author{
Daisuke Shimada ${ }^{1,2}$, Keiichi Kakui ${ }^{1}$ and Hiroshi Kajihara ${ }^{1}$ \\ ${ }^{1}$ Department of Natural History Sciences, Faculty of Science, Hokkaido University, Sapporo 060-0810, Japan \\ E-mail:d-shimada@mail.sci.hokudai.ac.jp (DS); k_kakui@mail.goo.ne.jp (KK); kazi@mail.sci.hokudai.ac.jp (HK) \\ ${ }^{2}$ Corresponding author
}

(Received 1 May 2012; Accepted 30 August 2012)

\begin{abstract}
A new species of free-living marine nematode, belonging to the genus Micoletzkyia Ditlevsen, 1926 (Phanodermatidae Filipjev, 1927), is described from the deep sea off the coast of Hokkaido, northern Japan. Micoletzkyia mawatarii sp. nov. resembles M. magna Vitiello, 1970 and M. longispicula Huang and Cheng, 2012 in the shape of the tail and gubernaculum, but differs from the former in body width and in length of the cephalic setae, and from the latter in body length, proportional length of the tail, position of the nerve ring, and shape of the precloacal supplement. Micoletzkyia mawatarii sp. nov. also resembles M. parelegans Allgén, 1954 in its large body size, but differs from it in esophagus length, shape of the gubernaculum, size and position of the precloacal supplement, and in having a longer tail.
\end{abstract}

Key Words: Nematoda, marine, deep sea, benthos, new species.

\section{Introduction}

The free-living marine nematode family Phanodermatidae Filipjev, 1927 is characterized mainly by the presence of a head capsule, a characteristic cellular structure in the esophageal region, and elongate spicules (cf. Filipjev 1927; Inglis 1964; Lorenzen 1981; Platonova 1984). The genus Micoletzkyia Ditlevsen, 1926 differs from the other genera of this family in having a large body size (most species are 5-10 $\mathrm{mm}$ long), a constriction separating the head region from the cervical region, a weak cephalic capsule, a tubular precloacal supplement, and a conico-cylindrical tail (cf. Ditlevsen 1926; Allgén 1954a; Huang and Cheng 2012). By 2012, nine valid species of Micoletzkyia [twelve nominal species are known, but three of them were recently judged invalid by Huang and Cheng (2012), whom we follow in the present paper] had been described from the bottom at depths of 25 to $580 \mathrm{~m}$ in European waters (Ditlevsen 1926; Stekhoven 1946; Allgén 1954b, c, 1959; Vitiello 1970; Gagarin 2009) and the Yellow and South China Seas (Huang and Cheng 2012).

During a cruise in 2009 to northern Japan by the R/V Soyo-Maru (National Research Institute of Fishery Science, NRIFS), several specimens of free-living nematode were collected. From this material, we here described a new species of Micoletzkyia.

\section{Material and Methods}

All specimens examined were collected at two deepsea sites in the Sea of Okhotsk and the Sea of Japan off the coast of Hokkaido, northern Japan, during a survey by R/V Soyo-Maru (31 July to 12 August 2009). Muddy sediment samples were floated from the bottom and caught with small plankton nets fixed inside a larger beam trawl (benthos net). Sediment samples were washed in seawater, then sieved with a plankton net $(450 \mu \mathrm{m}$ in mesh size) to collect small animals. Nematode specimens were sorted under a stereomicroscope and fixed in DESS solution (Yoder et al. 2006) containing DMSO (dimethyl sulphoxide), EDTA (ethylenediaminetetraacetic acid, disodium salt), and saturated sodium chloride. Nematodes were transferred into $10 \%$ glycerin in $30 \%$ ethanol, then placed in a thermostatic chamber for $48-72$ hours at $45^{\circ} \mathrm{C}$. After evaporation, nematodes were mounted individually in anhydrous glycerin on glass slides before observation with an Olympus BX51 differential interference contrast microscope. Other specimens were dried in a critical-point dryer, sputter-coated with $\mathrm{Au}$, and observed and imaged with a Hitachi S-3000N scanning electron microscope (SEM). All specimens examined were deposited in the Hokkaido University Museum, Sapporo, Japan, catalogued with the acronym ZIHU representing the former Zoological Institute, Hokkaido University.

Abbreviations related to measurements presented in the descriptions are: L, total body length; abd, body diameter at anus (in females) or cloaca (in males); mbd, maximum body diameter.

De Man's ratios are: a, body length divided by maximum body diameter; b, body length divided by esophagus length; c, body length divided by tail length; V, position of vulva as a percentage of body length from anterior end [all after Hooper (1986)]. 


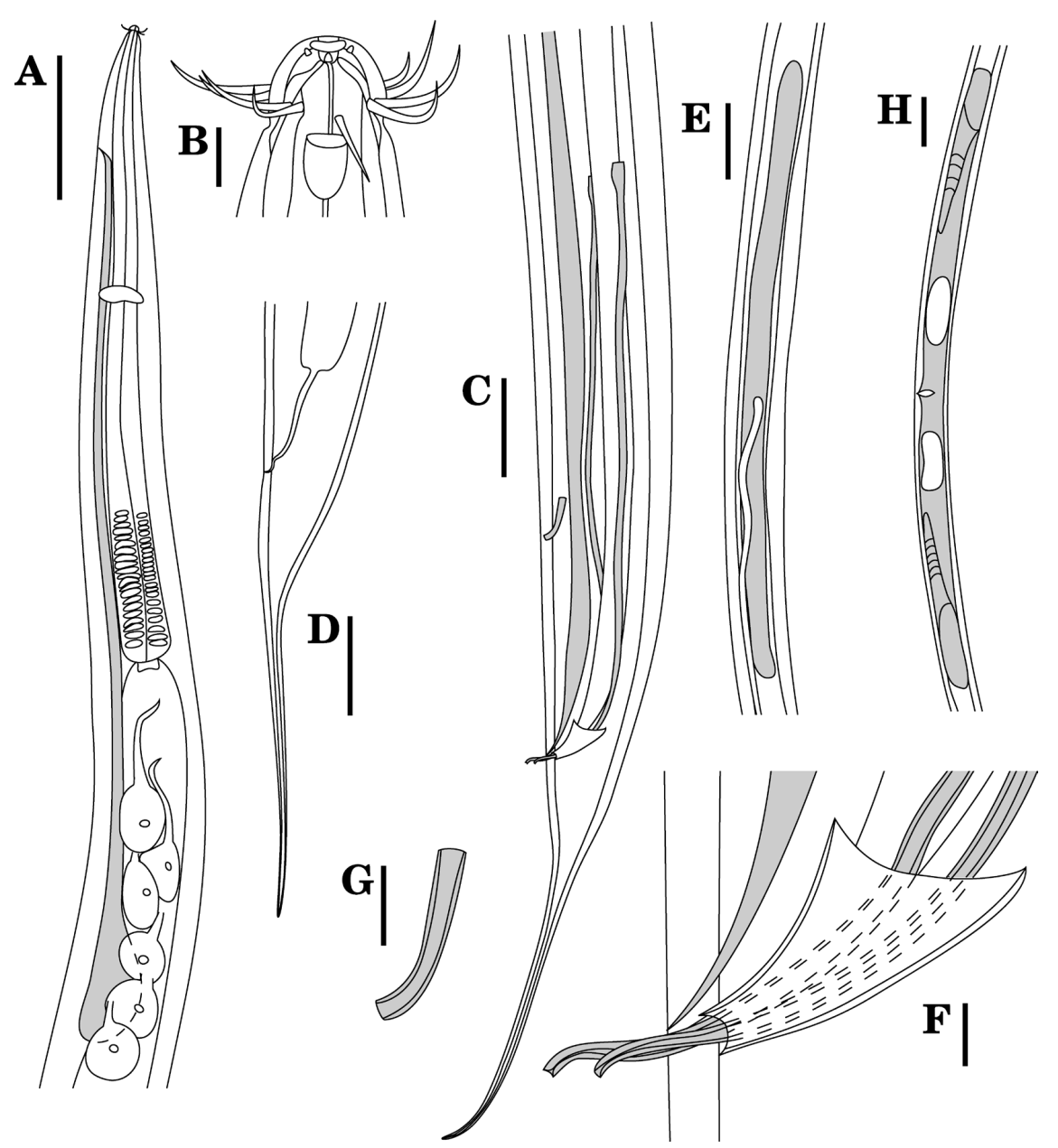

Fig. 1. Micoletzkyia mawatarii sp. nov., holotype, ZIHU 4073 (A-C, E-G) and paratypes, ZIHU 4075 (D) and ZIHU 4077 (H). A, anterior region of male body; $\mathrm{B}$, head of male; $\mathrm{C}$, posterior region of male body; $\mathrm{D}$, posterior region of female body; $\mathrm{E}$, reproductive system of male (testes and vas deferens); F, distal end of spicules and gubernaculum at cloacal region of male; G, precloacal supplement of male; $\mathrm{H}$, reproductive system of female (ovaries, uterus, eggs, and vulva). Scale bars: A, E, H, $200 \mu \mathrm{m} ; \mathrm{B}, 10 \mu \mathrm{m} ; \mathrm{C}, \mathrm{D}, 100 \mu \mathrm{m} ; \mathrm{F}, 10 \mu \mathrm{m} ; \mathrm{G}, 20 \mu \mathrm{m}$.

Family Phanodermatidae Filipjev, 1927

Subfamily Crenopharynginae Platonova, 1976

Genus Micoletzkyia Ditlevsen, 1926

Micoletzkyia mawatarii sp. nov.

(Figs 1-3)

Material examined. Four males and four females. Holotype. Male (ZIHU 4073), whole mount, collected on $5 \mathrm{Au}-$ gust 2009 by K. Kakui. Paratypes. One male (ZIHU 4074) and three females (ZIHU 4075-4077), whole mounts; one male (ZIHU 4078) and one female (ZIHU 4079), Au-coated SEM specimens; same collection data as for holotype. One male (ZIHU 4080), whole mount, collected on 2 August 2009 by K. Kakui.

Type locality and habitat. In muddy sediment, west of Musashi Bank, Sea of Japan $\left(44^{\circ} 41.5^{\prime} \mathrm{N}, 139^{\circ} 48.3^{\prime} \mathrm{E}\right)$, depth $528 \mathrm{~m}$.

Other locality and habitat. In muddy sediment, Sea of Okhotsk (44⒊ $\left.346^{\prime} \mathrm{N}, 144^{\circ} 41.7^{\prime} \mathrm{E}\right)$, depth $1,550 \mathrm{~m}$ (ZIHU 4080).

Etymology. The specific name mawatarii, a masculine noun in the genitive singular, honors Professor emeritus Shunsuke F. Mawatari (Hokkaido University) for his great contributions to invertebrate taxonomy in Japan.

Measurements (Table 1). Holotype: $\mathrm{L}=11.0 \mathrm{~mm}, \mathrm{mbd}=$ $196 \mu \mathrm{m}, \mathrm{a}=56.2, \mathrm{~b}=11.0, \mathrm{c}=24.0$. Males $(n=3$, including holotype): $\mathrm{L}=10.5-11.0 \mathrm{~mm}, \mathrm{mbd}=196-200 \mu \mathrm{m}, \mathrm{a}=52.4-$ $56.2, \quad \mathrm{~b}=9.8-11.0, \mathrm{c}=24.0-27.5$. Females $(n=3): \mathrm{L}=10.7$ $12.7 \mathrm{~mm}, \mathrm{mbd}=214-227 \mu \mathrm{m}, \mathrm{a}=47.2-58.6, \quad b=10.5-11.0$, $c=24.5-27.7, V=50.2-53.1$.

Description. Body long; anterior and posterior regions gradually tapering; anterior part of cervical region (Figs 1A, 2A) sharply tapering to anterior body end. Cuticle smooth; somatic setae sparse. Numerous large gland cells (Figs 1A, $3 \mathrm{~A}$ ) opening on cuticular surface around intestine, densely present particularly between anterior end of intestine and $30-40 \%$ from anterior end of body.

Head (Figs 1B, 2B, C) rounded at anterior end, set off by constriction just posterior to cephalic setae. Head diameter at level of cephalic setae $8-9 \%$ of mbd. Body diameter at constriction $0.5-1.3 \mu \mathrm{m}$ smaller than head diameter. Three low lips well developed. Labial and cephalic setae $6+6+4$ pattern (observed with SEM, but appearing $6+10$ under light microscopy); inner labial setae very short $(2-3 \mu \mathrm{m})$; outer labial setae 0.8-1.0 times head diameter; cephalic setae slightly shorter than outer labial setae, 0.6-0.9 times 
Table 1. Measurements of Micoletzkyia mawatarii sp. nov. (in $\mu \mathrm{m}$, except for a, b, c, and V).

\begin{tabular}{|c|c|c|c|c|c|c|}
\hline & \multicolumn{3}{|c|}{ Males } & \multicolumn{3}{|c|}{ Females } \\
\hline & \multicolumn{3}{|c|}{ ZIHU } & \multicolumn{3}{|c|}{ ZIHU } \\
\hline & $* 4073$ & 4074 & 4080 & 4075 & 4076 & 4077 \\
\hline $\mathrm{L}$ & 11008 & 10670 & 10474 & 11765 & 10717 & 12720 \\
\hline $\mathrm{a}$ & 56.2 & 54.4 & 52.4 & 55.0 & 47.2 & 58.6 \\
\hline b & 11.0 & 10.8 & 9.8 & 10.9 & 10.5 & 11.0 \\
\hline c & 24.0 & 25.9 & 27.5 & 24.5 & 27.7 & 26.4 \\
\hline V (\%) & & & & 50.2 & 53.1 & 51.2 \\
\hline head diameter at cephalic setae & 17.2 & 17.1 & 17.1 & 16.4 & 17.1 & 16.8 \\
\hline anterior end to head constriction & 12.5 & 12.9 & 12.8 & 12.4 & 12.0 & 11.4 \\
\hline body diameter at head constriction & 16.4 & 16.3 & 16.6 & 15.1 & 16.2 & 16.0 \\
\hline longest outer labial setae length & 17.5 & 16.9 & 17.1 & 14.5 & 16.6 & 13.3 \\
\hline shortest outer labial setae length & 16.9 & 16.3 & 16.6 & 14.2 & 16.3 & 12.8 \\
\hline longest cephalic setae length & 14.4 & 13.9 & 12.3 & 12.3 & 15.3 & 12.7 \\
\hline shortest cephalic setae length & 10.8 & 13.8 & 10.4 & 10.5 & 14.3 & 10.5 \\
\hline buccal cavity length & 3.6 & 4.3 & 3.5 & 3.8 & 4.4 & 5.0 \\
\hline buccal cavity width & 2.2 & 2.8 & 2.0 & 3.2 & 3.9 & 3.3 \\
\hline anterior end to amphid & 13.5 & 13.7 & 13.9 & 9.9 & 13.2 & 10.0 \\
\hline amphidal aperture width & 6.8 & 7.1 & 9.5 & 7.5 & 8.2 & 7.6 \\
\hline esophagus length & 1002 & 985 & 1074 & 1084 & 1025 & 1156 \\
\hline body diameter at base of esophagus & 156 & 152 & 175 & 175 & 186 & 181 \\
\hline anterior end to excretory pore & 193 & 215 & 249 & 200 & 208 & 197 \\
\hline anterior end to nerve ring & 413 & 383 & 447 & 451 & 463 & 509 \\
\hline body diameter at nerve ring & 108 & 113 & 114 & 117 & 123 & 119 \\
\hline ventral gland width & 85 & 89 & 92 & 37 & 56 & 32 \\
\hline $\begin{array}{l}\text { anterior end to posterior end of ventral } \\
\text { gland }\end{array}$ & 1538 & 1505 & 1577 & 1621 & 1575 & 1610 \\
\hline mbd & 196 & 196 & 200 & 214 & 227 & 217 \\
\hline abd & 86 & 92 & 89 & 83 & 81 & 86 \\
\hline tail length & 458 & 412 & 381 & 481 & 387 & 481 \\
\hline diameter at filiform part of tail & 11.7 & 12.2 & 10.5 & 12.1 & 11.5 & 14.3 \\
\hline anterior end to anterior testis & 3872 & 4617 & 4173 & & & \\
\hline $\begin{array}{l}\text { anterior end to posterior end of posterior } \\
\text { testis }\end{array}$ & 5352 & 6224 & 6475 & & & \\
\hline spicule length on arc (left/right) & $708 / 691$ & $632 / 664$ & & & & \\
\hline gubernaculum length & 63 & 61 & 62 & & & \\
\hline gubernaculum width at proximal end & 38 & 34 & 33 & & & \\
\hline gubernaculum width at distal end & 8 & 8 & 6 & & & \\
\hline precloacal supplement length & 49 & 49 & 47 & & & \\
\hline cloaca to precloacal supplement & 240 & 240 & 235 & & & \\
\hline anterior end to anterior ovary & & & & 4693 & 4305 & 4891 \\
\hline $\begin{array}{l}\text { anterior end to posterior end of posterior } \\
\text { ovary }\end{array}$ & & & & 7357 & 7003 & 8311 \\
\hline anterior end to vulva & & & & 5911 & 5689 & 6511 \\
\hline body diameter at vulva & & & & 166 & 184 & 171 \\
\hline
\end{tabular}

* Holotype.

head diameter. Cephalic capsule weak. Buccal cavity small, cylindrical, without teeth or denticles. Amphids pocket-like, just posterior to constriction; amphidal foveae deep, cup shaped; apertures oval, width 0.4-0.6 times head diameter.

Esophagus (Fig. 1A) gradually tapering to anterior end, length $9.1-10.3 \%$ of L. Excretory pore at $17-23 \%$ of esophagus from anterior end. Nerve ring at $39-45 \%$ of esophagus from anterior end. Cervical setae sparse. Ventral gland (Figs 1A, 3B) larger in males than in females; width 0.4-0.5 times corresponding body diameter in males, $0.2-0.3$ times in females. Posterior end of ventral gland situated at 1.4-1.5 times esophagus length from anterior end.

Tail (Figs 1C, D, 2D) conical in anterior third (27-36\%), filiform in posterior two-third; length 4.3-5.3 times abd in males, $4.8-5.8$ times in females; $3.6-4.2 \%$ of L. Abd $44-47 \%$ of mbd in males, $36-40 \%$ in females. Width of filiform part of tail $12-14 \%$ of abd in males, $14-17 \%$ in females. Several short setae in caudal and anal (cloacal) regions, but their arrangement varying among individuals. Tail acute at tip, with spinneret, but without terminal setae. Caudal gland inconspicuous.

Males. Reproductive system (Fig. 1E) diorchic. Testes 

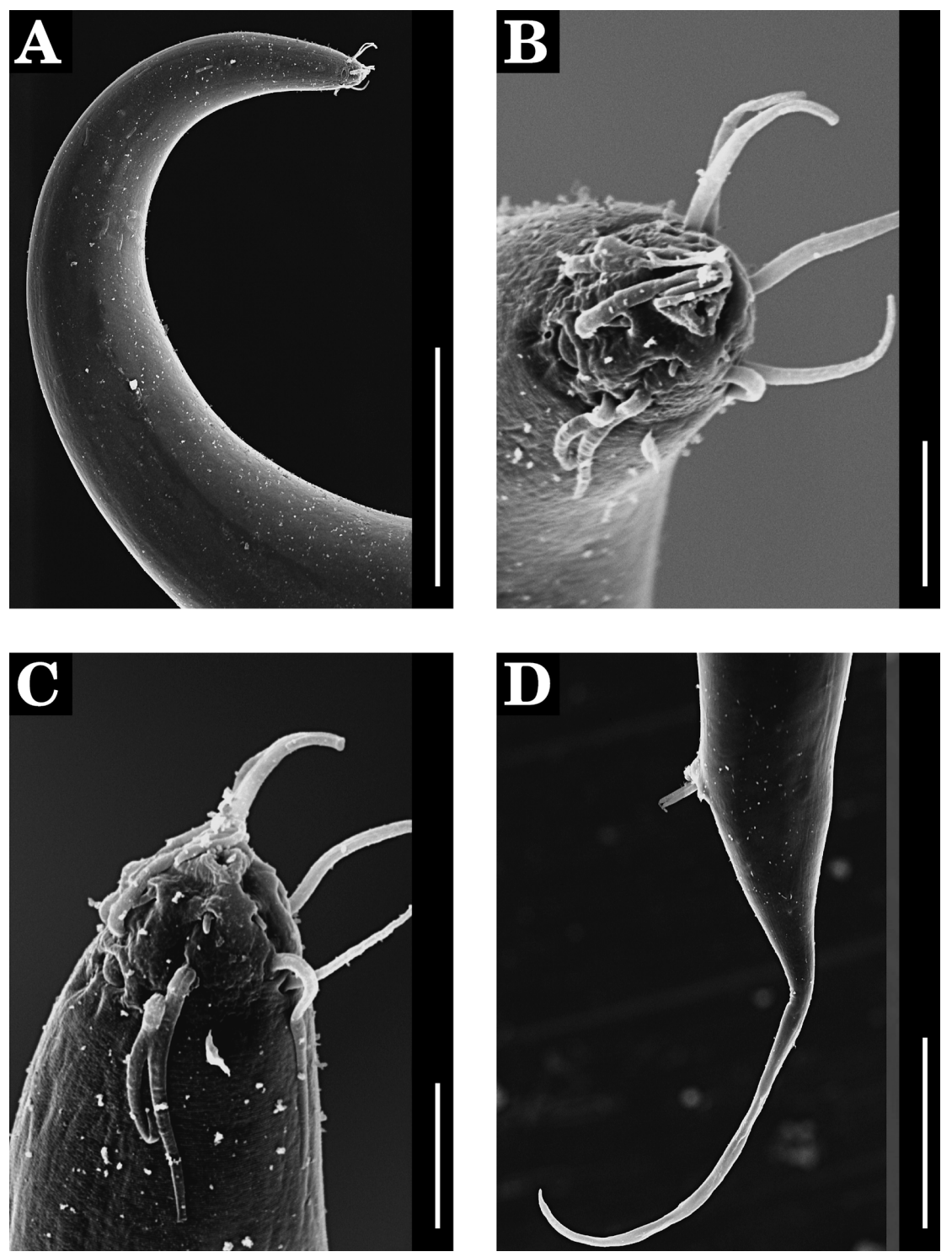

Fig. 2. SEM images of Micoletzkyia mawatarii sp. nov., paratypes, ZIHU 4079 (A-C) and ZIHU 4078 (D). A, lateral view of anterior region of female body; B, anterior view of female head; C, ventrolateral view of female head; D, lateral view of posterior region of male body. Scale bars: A, D, $100 \mu \mathrm{m} ; \mathrm{B}, \mathrm{C}, 10 \mu \mathrm{m}$.
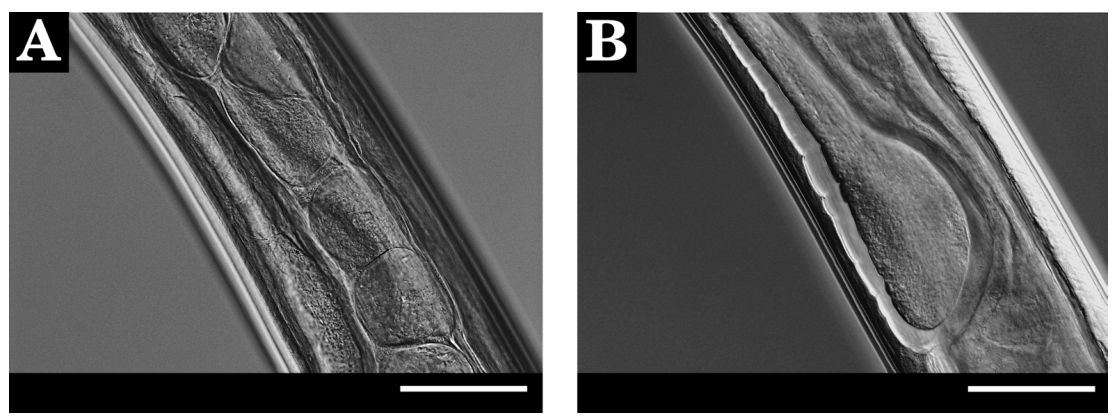

Fig. 3. Light photomicrographs of Micoletzkyia mawatarii sp. nov., holotype, ZIHU 4073. A, gland cells surrounding intestine; B, ventral gland. Scale bars: $100 \mu \mathrm{m}$.

equal, opposed, outstretched; anterior testis beginning at $35-43 \%$ of $\mathrm{L}$, posterior testis ending at $49-62 \%$ of $\mathrm{L}$ from anterior body end. Spicules (Fig. 1C, F) paired, equal, proximally expanded, bent ventralwards, distally acute (spicules broken in ZIHU 4080); length 6.9-8.2 times abd, 1.5-1.6 times tail length, 16-17\% of L. Gubernaculum (Fig. 1C, F) surrounding spicules, conical, strongly tapering to distal end, without apophysis; 9-10\% of spicule length. Precloacal supplement (Fig. 1C, G) tubular, without accessory structure; length $7-8 \%$ of spicule; situated at $2.6-2.8$ times abd 
anterior to cloaca.

Females. Reproductive system (Fig. 1H) didelphic. Ovaries equal, opposed, reflexed; anterior ovary beginning at $38-40 \%$ of L, posterior ovary ending at $63-65 \%$ of $\mathrm{L}$ from anterior body end. Eggs (found only in ZIHU 4077) oval, $317-362 \mu \mathrm{m}$ long, $137-139 \mu \mathrm{m}$ wide, numbering 2 in uterus. Vulva situated at $50-53 \%$ of L from anterior body end; corresponding body diameter $78-81 \%$ of mbd.

Diagnosis. Micoletzkyia mawatarii sp. nov. is characterized by its large body size $(\mathrm{L}=10.5-11.0 \mathrm{~mm}, \mathrm{mbd}=$ $196-200 \mu \mathrm{m}$ in males; $\mathrm{L}=10.7-12.7 \mathrm{~mm}, \mathrm{mbd}=214-227 \mu \mathrm{m}$ in females); particular ranges of De Man's ratios $(a=52.4-$ $56.2, b=9.8-11.0, c=24.0-27.5$ in males; $a=47.2-58.6, b=$ $10.5-11.0, c=24.5-27.7, V=50.2-53.1$ in females); long outer labial setae (length $0.8-1.0$ times head diameter); short esophagus for the body length (9-10\% of L); long spicules (632-708 $\mu \mathrm{m}, 6.9-8.2$ times as long as abd); conical gubernaculum with no apophysis; simple, tubular precloacal supplement with no accessory appendage; and long tail (381$458 \mu \mathrm{m}, 4.3-5.3$ times as long as abd in males, $387-481 \mu \mathrm{m}$, 4.8-5.8 times abd in females).

Micoletzkyia mawatarii resembles M. magna Vitiello, 1970 and M. longispicula Huang and Cheng, 2012 in the shape of the tail (anterior ca. 30\% conical, posterior $70 \%$ filiform), and the shape of the gubernaculum (conical and tapering to the distal end, without any apophysis), but differs from M. magna in the body diameter (maximally 196$200 \mu \mathrm{m}, \mathrm{a}=52.4-56.2$ in males of $M$. mawatarii $v s 113 \mu \mathrm{m}$, $\mathrm{a}=71.4$ in $\mathrm{M}$. magna), and the lengths of the outer labial and cephalic setae $(10.4-17.5 \mu \mathrm{m}, 0.6-1.0$ times head diameter $v s$ about $6 \mu \mathrm{m}$, less than 0.5 times head diameter) (cf. Vitiello 1970). Micoletzkyia mawatarii also differs from M. longispicula in body size $(\mathrm{L}=10.5-11.0 \mathrm{~mm}, \mathrm{mbd}=196-200 \mu \mathrm{m} v s$ $6.1 \mathrm{~mm}, 128 \mu \mathrm{m}$ in M. longispicula), the proportional length of the tail (4.3-5.3 times as long as abd, $\mathrm{c}=24.0-27.5$ vs 6.5 times abd, $c=14.2$ ), the position of the nerve ring (situated $39-42 \%$ of way from anterior end of the esophagus $v s$ about mid-way along esophagus), and the simple tubular precloacal supplement ( $v$ s tubular with a head-like proximal end in M. longispicula) (cf. Huang and Cheng 2012). Micoletzkyia mawatarii also resembles $M$. parelegans Allgén, 1954 in its large body size $(\mathrm{L}>10 \mathrm{~mm})$, but differs from the latter in esophagus length $(b=9.8-11.0$ vs 7.1$)$, shape of the gubernaculum (cylindrical, surrounding the spicules $v s$ tubular or plate-like in M. parelegans), size and the position of the precloacal supplement ( $47-49 \mu \mathrm{m}$ long, $235-240 \mu \mathrm{m}$ from the cloaca $v s 68 \mu \mathrm{m}$ long, $350 \mu \mathrm{m}$ from the cloaca), and length of the tail (more than 4 times abd, $c=24.0-27.5$, vs about 2 times abd, c=45.6) (cf. Allgén 1954b, c).

Remarks. This is the 10th species known in Micoletzky$i a$, and the deepest record (ZIHU 4080 were collected from $1,550 \mathrm{~m}$ deep) for the genus. Although 12 nominal species have been described in the genus, Huang and Cheng (2012) considered M. anomala Wieser, 1953, M. austrogeorgiae Allgén, 1954, and M. falklandiae Allgén, 1954 to be invalid because of their incomplete descriptions based on immature female or juvenile specimens. Therefore, the genus Micoletzkyia contains 10 species, viz., M. elegans Ditlevsen, 1926 (type species), M. parelegans, M. nudicapitata Allgén, 1959, M. magna, M. mucronata Vitiello, 1970, M. sedata Gagarin, 2009, M. filicaudata, M. longispicula, M. nanhaiensis Huang and Cheng, 2012, and M. mawatarii sp. nov.

Referring to the identification key by Huang and Cheng (2012), M. mawatarii can be classified in the same category as M. magna, M. elegans, M. longispicula, and M. sedata (fifth choice in the key) by its having a tail with a long filiform part. The following key distinguishes these five species. Because measurements of $M$. elegans vary between the original description (Ditlevsen 1926) and redescriptions (Stekhoven 1946; Allgén 1954a), we only follow the original description.

1. Longest outer labial or cephalic setae much shorter than head diameter .............. M. magna Vitiello

- Longest outer labial or cephalic setae almost equal to or longer than head diameter................. 2

2. Gubernaculum of peculiar, complex shape ..........

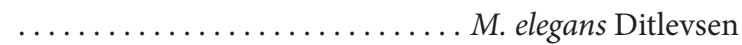

- Gubernaculum simple ..................... 3

3. Spicule shorter than 5 abd, gubernaculum $23 \mu \mathrm{m} . \ldots$. ........................... sedata Gagarin Spicule longer than 6 abd, gubernaculum 51-63 $\mu \mathrm{m}$. . 4

4. Nerve ring midway along esophagus, $c=14.2$, precloacal supplement with head-like proximal end. ........ .............. M. longispicula Huang and Cheng - Nerve ring 39-42\% of esophagus length, c=24.0-27.5, precloacal supplement unmodified tubular......... ....................... mawatarii sp. nov.

\section{Acknowledgements}

We wish to thank Prof. Matthew H. Dick, Hokkaido University, for his careful reading of the manuscript as well as valuable comments and suggestions. We also thank Ken Fujimoto and Takami Morita of NRIFS for providing the nematodes used in this study, and the captain and the crew of the R/V Soyo-Maru for their kind cooperation in collecting specimens.

\section{References}

Allgén, C. A. 1954a. Micoletzkyia, eine bemerkenswerte marine Nematodengattung. Zoologischer Anzeiger 152: 134-137.

Allgén, C. A. 1954b. Freeliving marine nematodes from East Greenland and Jan Mayen. The Swedish Greenland Expedition 1899. Meddelelser om Grønland 107(6): 1-44.

Allgén, C. A. 1954c. Kleine Mitteilungen über freilebende Nematoden I-IV. Zoologischer Anzeiger 153: 88-95.

Allgén, C. A. 1959. Further Zoological Results of the Swedish Antarctic Expedition 1901-1903. Vol. 5. No. 2. Freeliving Marine Nematodes. Kungl. Boktryckeriet P. A. Norstedt \& Söner, Stockholm, 293 pp.

Ditlevsen, H. 1926. The Danish Ingolf-Expedition. Volume 4. No. 6. Free-living Nematodes. Bianco Luno, Copenhagen, 42 pp., 15 pls.

Filipjev, I. N. 1927. Les nématodes libres des mers septentrionales appartenant à la famille des Enoplidae. Archiv für Naturgeschichte, 
Abteilung A, Original-Arbeiten 91 (6): 1-216, 7 pls.

Gagarin, V. G. 2009. New species of enoplids (Nematoda: Enoplida) from Mediterranean Sea. Zoologiya Bespozvonochnykh 6: 117127. [In Russian with English abstract]

Hooper, D. J. 1986. Drawing and measuring nematodes. Pp. 87-94. In: Southey, J. F. (Ed.) Laboratory Methods for Work with Plant and Soil Nematodes. 6th Edition. Her Majesty's Stationery Office, London, $202 \mathrm{pp}$.

Huang, Y. and Cheng, B. 2012. Three new free-living marine nematode species of the genus Micoletzkyia (Phanodermatidae) from China Sea. Journal of the Marine Biological Association of the United Kingdom 92: 941-945.

Inglis, W. G. 1964. The marine Enoplida (Nematoda): a comparative study of the head. Bulletin of British Museum (Natural History). Zoology 11: 265-376.

Lorenzen, S. 1981. Entwurf eines phylogenetischen Systems der freilebenden Nematoden. Veröffentlichungen des Instituts für Meeresforschung in Bremerhaven (Supplement 7): 1-472. [English translation by Platt, H. M.: Lorenzen, S. 1994. The Phylogenetic Systematics of Freeliving Nematodes. Ray Society, London, 383 pp.]

Platonova, T. A. 1976. Nizshie Enoplida (svobodnozhivushchie morskie nematody) morei SSSR. Pp. 3-164. In: Platonova, T. A. and Gal'tsova, V. V. (Eds) Nematody i ikh Rol v Meiobentose [Nematodes and their Role in the Meiobenthos]. Nauka Publishers, Leningrad, 270pp. [In Russian, English translation by Sharma, S.: Platonova, T. A. 1985. Lower Enoplida of the seas of the Soviet Union. Pp. 1-214. In: Platonova, T. A. and Gal'tsova, V. V. (Eds) Nematodes and their Role in the Meiobenthos. Amerind Publishing Co. Pvt. Ltd., New Delhi, v+366 pp.]

Platonova, T. A. 1984. Materials for the revision of the family Phanodermatidae (Enoplida, Nematoda). Zoologicheskii Zhurnal 63: 507-516. [In Russian with English summary]

Stekhoven, J. H. S. 1946. Freilebende marine Nematoden des Skageraks und der Umgebung von Stockholm. Arkiv för Zoologi 37A(16): $1-91$.

Vitiello, P. 1970. Nématodes libres marins des vases profondes du Golfe du Lion. I. Enoplida. Tethys (Marseille) 2: 139-210.

Yoder, M., Tandingan De Lay, I., King, I. W., Mundo-Ocampo, M., Mann, J., Blaxter, M., Poiras, L. and De Ley, P. 2006. DESS: a versatile solution for preserving morphology and extractable DNA of nematodes. Nematology 8: 367-376. 